\title{
Effect of Hot Air Drying Variables on Phytochemicals and Antioxidant Capacity of Jew's Mallow (Corchorus olitorius L.) Leaves
}

\author{
Youssef, Kh. M.*; S. M. Mokhtar and Noha E. Morsy \\ Food Technology Department, Faculty of Agriculture, Suez Canal University, 41522, Ismailia, Egypt.
}

Received: $9 / 10 / 2014$

\begin{abstract}
Jew's mallow (Corchorus olitarius L.) is an important vegetable in Egypt. Fresh or dried Jew's mallow leaves have a wide use and is great demand for domestic as well as export markets. The effects of hot air drying variables including: air temperature $\left(50,60\right.$ and $\left.70{ }^{\circ} \mathrm{C}\right)$, air velocity $(0.2,0.4$ and $0.6 \mathrm{~m} / \mathrm{s})$ and trays load $(125-500 \mathrm{~g} / 0.22 \mathrm{~m}$ ) on the antioxidant capacity and some phytochemicals content of Jew's mallow leaves were studied. The fresh Jew's mallow leaves exhibited high antioxidant activity $(52.29 \%$ and $139.55 \mu \mathrm{mol}$ trolox/ g dry weight, measured by DPPH and ABTS assays, respectively). The leaves had high contents of chlorophyll a and b (649.4 and $317.4 \mathrm{mg} / 100 \mathrm{~g})$, total phenolics (16.54 mg GAE/ g) and total flavonoids (117.88 mg quercetin equivalent/ g). Drying process resulted in drastic decreases in all studied properties except the $\beta$-carotene content. Antioxidant activity and phytochemicals compounds contents decreased as air drying temperature and velocity decreased, relating to long drying times. Drying at $60{ }^{\circ} \mathrm{C}$ and air velocity $0.6 \mathrm{~m} / \mathrm{s}$ had the lowest negative effect on the leaves antioxidant activity. Leaves dried at the highest trays load $\left(500 \mathrm{~g} / 0.22 \mathrm{~m}^{2}\right)$ also, showed the highest antioxidant activity and phytochemicals contents.
\end{abstract}

Keywords: Jew's mallow, air drying, antioxidant capacity, phenolics, flavonoids, chlorophylls

\section{INTRODUCTION}

Corchorus olitorius L. (known by several names such as Jew's mallow, Molokhia or Egyptian spinach) is a leafy summer vegetable that grows in subtropical and tropical regions (Handoussa et al., 2013). It has been produced as a very important vegetable in Egypt, Japan, China and Middle East countries. Although, it is an important leafy vegetable cultivated in many countries, no statistical data on the production and trading are available. Fresh leaves and tender shoots are essential parts (Phuwapraisirisan et al., 2009). The leaves are nutritious, rich in beta-carotene, chlorophylls, phenolics, minerals, protein, folate, vitamins, fatty acids and dietary fiber. The health benefits have been reported in antitumor promotion (Furumoto et al., 2002), antioxidant properties (Azuma et al., 1999), antibacterial activity (Zakaria et al., 2006), decrease serum and liver cholesterol (Innami et al., 1995), managing diabetes and hypertension (Oboh et al., 2012). Its' cold infusion found to be restore the appetite and strength (Adegoke and Adebayo-Tayo, 2009).

Phytochemicals are substances found naturally in plant foods, including vegetables. Increased consumption of vegetables rich in phytochemicals correlates with increased cardiovascular health and reduced the risk of several age-related diseases such as cancer, stroke, cataract, degenerative diseases, loss of functionality and Alzheimer's disease. Levels of individual antioxidants in food do not necessarily reflect their antioxidant capacity, which could depend on synergic and redox interactions among the different antioxidant molecules present in the food (Hunter and Fletcher, 2002; Dai et al., 2006; Murcia et al., 2009 and Pappas and Schaich, 2009). Phenolic compounds are a category of phytochemicals that exert strong antioxidant properties. They can be classified into simple phenols, phenolic acids, hydroxycinnamic acid derivatives, lignans, lignins and flavonoids (Decker, 1995). Flavonols and flavones are located predominantly in the leaves and outer parts of the plants (Hertog and Hollman, 1996). The antioxidant activity of phenolics is based on the redox properties of their hydroxyl groups, which allow them to act as reducing agents, hydrogen donors, single oxygen quenchers and metal chelators (Oboh and Rocha, 2007). Two new flavonol glycosides named corchorusides $\mathrm{A}$ and $\mathrm{B}$ were isolated from leaf extract of Corchorus olitorius. Corchoruside A comprises a kaempferol moiety connected with caffeic acid, glucose and a rare methyl glucuronate. Caffeoyl moiety occurred in corchoruside A enhanced its inhibitory effect toward $\alpha$-glucosidase (Phuwapraisirisan et al., 2009).

Dehydration is one of the most widely used methods for vegetables preservation. The marketing of dehydrated vegetables has increased over recent years to provide long-shelf life products which are easy to handle and store and used in formulation of nutraceutical products. Food products are sensitive to drying conditions such as temperature, air velocity and relative humidity, which can cause physical, structural, chemical and nutritional changes that, can affect quality attributes of products (Vega-Gálvez et al., 2009). The drying of Jew's mallow leaves is necessary and commonly used to preserve it. Many studies investigated the changes in the quality parameters of Jew's mallow leaves during different drying methods (Ali and Sokr, 1982; Hussein, 1983 and Bahlol et al., 2000). But, there is no data on the effect of drying process on the antioxidant properties and phytochemical compounds content of Jew's mallow leaves. Thus, the objective of this study was to investigate, for the first time, the effect of hot air drying conditions (air temperature, air velocity and trays load) on the antioxidant activity and phytochemical compounds of Jew's mallow leaves. 


\section{MATERIALS AND METHODS}

\section{Materials: \\ Plant material:}

Fresh harvested Jew's mallow (Corchorus olitorius L.) was purchased from a local market (Ismailia Governorate, Egypt) during August and September 2013. Green leaves were separated from plant, washed with tap water and then drained and left to dry on a cheese cloth for $15 \mathrm{~min}$ at room temperature $\left(31 \pm 2^{\circ} \mathrm{C}\right)$. The moisture content of the fresh Jew's mallow leaves was immediately determined according to the AOAC (2000) method (number 934.01), and found to be $87.0 \pm$ $0.1 \mathrm{~g}$ water per $100 \mathrm{~g}$ sample.

\section{Chemicals and reagents:}

Folin-Ciocalteu's phenol reagent, anhydrous sodium carbonate, gallic acid, aluminum chloride and sodium hydroxide were purchased from Fluka. Sodium nitrite, quercetin, 2.2-diphenyl-1-picrylhydrazyl (DPPH), 6hydroxy-2,5,7,8-tetramethylchroman-2-carboxylic acid (trolox), potassium persulfate and 2,2'-azino-bis (3ethylbenzothiazoline-6-sulfonic acid) diammonium salt (ABTS) were obtained from Sigma-Aldrich CO. Methanol, hexane and acetone (analytical grade) were from Scharlab.

\section{Methods:}

\section{Drying treatments:}

To study the effect of drying air temperature on the antioxidant activity and phytochemical compounds of the dried product, $250 \mathrm{~g}$ of Jew's mallow leaves were spread uniformly onto stainless steel trays of size 36.5 $\mathrm{cm} \times 60 \mathrm{~cm}$. The leaves were dried in a convective dryer (WT-binder, type F115, Germany) at 50, 60 and $70^{\circ} \mathrm{C}$. The air velocity was set at $0.6 \mathrm{~m} / \mathrm{s}$ as measured with digital anemometer (VWR, Ireland) and ambient relative humidity $(32 \%)$. The drying time required to reach the equilibrium moisture content was $405 \pm 8,300$ \pm 15 and $195 \pm 8 \mathrm{~min}$ and the moisture content of the dried leaves was $9.35 \pm 0.45,8.75 \pm 0.95$ and $8.15 \pm$ $0.95 \mathrm{~g}$ water per $100 \mathrm{~g}$ leaves dried at 50,60 and $70^{\circ} \mathrm{C}$, respectively.

To study the effect of air velocity, $125 \mathrm{~g}$ of Jew's mallow leaves were spread onto stainless steel trays and dried in an oven at $0.2,0.4$ and $0.6 \mathrm{~m} / \mathrm{s}$ at a constant air temperature $\left(60^{\circ} \mathrm{C}\right)$ and ambient relative humidity. The drying time required to reach the equilibrium moisture content was $270 \pm 8,225 \pm 0$ and $195 \pm 8 \mathrm{~min}$ and the moisture content of the samples was $9.25 \pm 0.15,9.25 \pm$ 0.35 and $9.00 \pm 0.30 \mathrm{~g}$ water per $100 \mathrm{~g}$ leaves dried at $0.2,0.4$ and $0.6 \mathrm{~m} / \mathrm{s}$, respectively.

To study the effect of trays load, 125, 250, 375 and $500 \mathrm{~g}$ of fresh Jew's mallow leaves were spread uniformly onto stainless steel trays of size $36.5 \mathrm{~cm} \mathrm{X} 60$ $\mathrm{cm}$ and dried at $60^{\circ} \mathrm{C}$, an air velocity of $0.6 \mathrm{~m} / \mathrm{s}$ and ambient relative humidity $(32 \%)$. The drying time was $240 \pm 8,300 \pm 15,345 \pm 15$ and $420 \pm 30 \mathrm{~min}$ and the moisture content of the dried samples was $8.90 \pm 0.70$, $8.75 \pm 0.95,8.60 \pm 0.80$ and $8.40 \pm 1.10 \mathrm{~g}$ water per 100 $\mathrm{g}$ leaves at $125,250,375$ and $500 \mathrm{~g}$ trays load, respectively.
The drying experiments were conducted in triplicate. All samples were ground and passed through $250 \mu \mathrm{m}$ sieve previous to analyze.

\section{Determination of Pigments:}

The $\beta$-carotene, chlorophyll $\mathrm{a}$ and $\mathrm{b}$ contents were determined with the method described by Barros et al. (2011) with some modifications as follows: A $200 \mathrm{mg}$ of minced fresh or dried leaves powder was vigorously shaken with $10 \mathrm{ml}$ of acetone-hexane mixture $(4: 6)$ for 5 min and filtered through filter paper No. 102. The extract was adjusted to $10 \mathrm{ml}$ with volumetric flask. The absorbance of the extract was measured at 453, 505, 645 and $663 \mathrm{~nm}$ using a spectrophotometer (6505 UV/ VIS, Jenway LTD, Felsted, Dunmow, UK). Contents of $\beta$ carotene, chlorophyll a and $\mathrm{b}$ were calculated according to the following equations:

$\beta$-carotene $(\mathrm{mg} / 100 \mathrm{ml})=0.216 \times \mathrm{A}_{663}-1.220 \times \mathrm{A}_{645}-$ $0.304 \times \mathrm{A}_{505}+0.452 \times \mathrm{A}_{453}$;

Chlorophyll a $(\mathrm{mg} / 100 \mathrm{ml})=0.999 \times \mathrm{A}_{663}-0.0989 \times \mathrm{A}_{645}$; Chlorophyll b (mg/ $100 \mathrm{ml})=-0.328 \times \mathrm{A}_{663}+1.77 \times \mathrm{A}_{645}$, and further expressed in mg per $100 \mathrm{~g}$ dry weight.

Preparation of total phenolics, total flavonoids and antioxidants extracts:

Recent studies reported that the yield of extractable compounds was highest in methanol extract in comparison with the solvents such as ethyl acetate and water (Hossain and Rahman, 2011). Furthermore, the extraction of total phenolic compounds from the plant samples is commonly achieved with methanol or aqueous methanol (Antolovich et al., 2000). Thus, methanol was used as a solvent to prepare the antioxidants and bioactive compounds extract according to the method described by Barros et al. (2011) with some modifications as follows: one gram of minced fresh Jew's mallow leaves or fine dried powder was stirred with $25 \mathrm{ml}$ of methanol at $100 \mathrm{rpm}$ on Orbital Shaker (LAB-LINE Instruments, Inc., USA) for $1 \mathrm{~h}$ at room temperature $\left(35 \pm 1^{\circ} \mathrm{C}\right)$ and then filtered through filter paper No. 102. The residue was re-extracted with $25 \mathrm{ml}$ of methanol. The methanol extracts were combined and stored at $4{ }^{\circ} \mathrm{C}$ until further analyses. The extract was diluted if necessary.

\section{Determination of total phenolics content:}

Total phenolics content was calculated in the methanolic extract, according to the Folin-Ciocalteu assay with slight modifications (Barros et al., 2011). One $\mathrm{ml}$ aliquot of the extract (diluted 1:5 with water) was mixed with $5 \mathrm{ml}$ of Folin-Ciocalteu phenol reagent (diluted with water $1: 10 \mathrm{v} / \mathrm{v}$ ) and $4 \mathrm{ml}$ of sodium carbonate $(75 \mathrm{~g} / \mathrm{L})$. The tubes were vortexed for $30 \mathrm{~s}$ and allowed to stand for $60 \mathrm{~min}$ at room temperature $(30 \pm$ $1^{\circ} \mathrm{C}$ ) for color development. The absorbance was measured at $765 \mathrm{~nm}$ by spectrophotometer. A calibration curve $\left(R^{2}=0.9979\right)$ of gallic acid $(0-0.10$ $\mathrm{mg} / \mathrm{ml}$ ) was prepared and treated in similar conditions. The results were expressed as $\mathrm{mg}$ of gallic acid equivalents per gram of dry weight (mg GAE/g DW). 


\section{Determination of total flavonoids content:}

Total flavonoids content was determined by technique modified by Dewanto et al. (2002) and reported by Barros et al. (2011). Briefly $0.5 \mathrm{ml}$ aliquot of the extract was mixed with $2 \mathrm{ml}$ of distilled water followed by addition of $0.15 \mathrm{ml}$ of $\mathrm{NaNO}_{2} \quad(5 \%)$ solution. After $6 \mathrm{~min}, 0.15 \mathrm{ml}$ of $\mathrm{AlCl}_{3}$ solution (10\%) was added and allowed to stand for another $6 \mathrm{~min}$ before $2 \mathrm{ml}$ of $\mathrm{NaOH}$ solution $(4 \%)$ was added. The mixture was brought to $5 \mathrm{ml}$ with distilled water. Then the mixture was mixed well and allowed to stand for 15 min. The absorbance was measured at $510 \mathrm{~nm}$. A calibration curve of quercetin was prepared and total flavonoids content was determined from the linear regression equation $\left(\mathrm{R}^{2}=0.9996\right)$ of the calibration curve. The results were expressed as $\mathrm{mg}$ quercetin equivalents per gram of dry sample.

Determination of DPPH radical-scavenging activity:

The antioxidant activity of the extract was determined by DPPH method described by Lee et al. (2003) and modified by Ravichandran et al. (2013). Shortly, $0.1 \mathrm{ml}$ of a 5-fold dilution of the methanol extracts was mixed for $30 \mathrm{~s}$ with $3.9 \mathrm{ml}$ of DPPH solution $\left(6 \times 10^{-5} \mathrm{M}\right)$, and left to react for $30 \mathrm{~min}$, after which the absorbance of the mixture was measured at $515 \mathrm{~nm}$. The DPPH solution without extract was analyzed as blank. The antioxidant activity was calculated as follows:

DPPH radical-scavenging activity $(\%)=\left[\left(\mathrm{A}_{\mathrm{blank}}\right.\right.$ $\left.\left.\mathrm{A}_{\text {sample }}\right) / \mathrm{A}_{\text {blank }}\right] \mathrm{x} 100$, where $\mathrm{A}$ is the absorbance at $515 \mathrm{~nm}$.

\section{$\mathrm{ABTS}^{++}$assay (trolox equivalent antioxidant capacity, TEAC):}

Additionally to DPPH investigations, the ability of the samples extract to scavenge the $\mathrm{ABTS}^{\circ+}$ radical was determined using the trolox equivalent antioxidant capacity (TEAC) assay. The method modified by Rufino et al. (2010) was used. Briefly, $\mathrm{ABTS}^{\circ+}$ radical cations were produced by reacting $7 \mathrm{mM}$ ABTS stock solution with $145 \mathrm{mM}$ potassium persulfate and allowing the mixture to stand in the dark at room temperature for $12 \mathrm{~h}$ before use. The $\mathrm{ABTS}^{\circ+}$ solution was diluted with ethanol to an absorbance of $0.720 \pm$ 0.022 at $734 \mathrm{~nm}$. After addition of $20 \mu \mathrm{l}$ of the sample extract or trolox standard to $4 \mathrm{ml}$ of diluted ABTS $^{\cdot+}$ solution, absorbance was recorded after $6 \mathrm{~min}$ of mixing. Ethanolic solutions of known trolox concentrations $(0-10 \mu \mathrm{g}$ per $\mathrm{ml})$ were used for calibration $\left(\mathrm{R}^{2}=0.9988\right)$ and results were expressed as $\mu \mathrm{mol}$ trolox per gram dry sample.

\section{Statistical analysis:}

Each experiment was done in triplicate. The results were expressed as mean \pm standard deviation and were analyzed by SPSS (version 17.0 SPSS Inc). One-way analysis of variance was performed using ANOVA procedures. Significant differences between the means were determined by Duncan's Multiple Range test. P < 0.05 was considered as a level of significance.

\section{RESULTS AND DISCUSSION}

Effect of hot air drying variables on chlorophyll a, b and $\beta$-carotene contents of Jew's mallow leaves:

Chlorophylls $\mathrm{a}$ and $\mathrm{b}$ are the major pigments of green vegetables, and they are usually present at a ratio of 2-3: 1 (von Elbe and Schwartz, 1996). Fresh Jew's mallow leaves contained $649.4 \pm 22.2,317.4 \pm 23.9$ and $91.4 \pm 12.1 \mathrm{mg} / 100 \mathrm{~g}$ (dry weight) of chlorophyll a, chlorophyll $b$ and $\beta$-carotene, respectively (Table 1). Labib et al. (1997) found that the minced Jew's mallow leaves without any treatment contained 207 and $130 \mathrm{mg} /$ $100 \mathrm{~g}$ (dry weight) of chlorophyll a and b, respectively. Also, Bahlol et al. (2000) found that the fresh Jew's mallow leaves contained 281.6, 225.6 and $150.8 \mathrm{mg} /$ $100 \mathrm{~g}$ (dry weight) of chlorophyll a, b and total carotenoids, respectively. These differences may be due to the variety, environmental conditions and extraction or method of determination.

Drying process variables (temperature, air velocity and trays load) led to significant decrease in the contents of chlorophyll $\mathrm{a}$ and $\mathrm{b}$ of the leaves (Table 1). The temperature had the main effect on these pigments. The decrements reached about 84.00 and $92.03 \%$ in the case of drying at $50^{\circ} \mathrm{C}$ with constant air velocity $(0.6$ $\mathrm{m} / \mathrm{s})$ and trays load $\left(250 \mathrm{~g} / 0.22 \mathrm{~m}^{2}\right)$ for chlorophyll a and $b$, respectively. This may be due to the effect of heat or to the partial activity of native chlorophyllases (Labib et al., 1997). Matile et al. (1999) found that, chlorophyllase catalyzes the first step in chlorophyll catabolism to form chlorophyllide. Also, chlorophyll is degraded by peroxidases or chlorophyll-degrading peroxidase (Martínez et al, 2001) or by lipoxygenase through the oxidation of linolenic acid (Matile et al., 1999). The retained chlorophyll a and b contents of the dried leaves significantly increased with increasing drying temperature. Moreover, the retained contents not significantly increased with increasing either air velocity or trays load. This may be due to combined effect of air velocity, drying time and drying air temperature. Chlorophyll retention during processing depends on the heating temperature and length of heat treatment. High-temperature short time processing has been made to preserve chlorophylls during heat processing (Schwartz and Lorenzo, 1991).

Carotenoids, including $\beta$-carotene, are known to be more stable during heating compared to chlorophylls (Lee et al, 2001). Carotenoids are not only important vitamin A precursors, but display a considerable level of antioxidant activity. There were no significant differences in $\beta$-carotene of fresh or dried Jew's mallow leaves at different air temperatures, air velocities and trays loads (Table 1). Hot air drying at low temperature $\left(50{ }^{\circ} \mathrm{C}\right)$ and trays load $\left(125 \mathrm{~g} / 0.22 \mathrm{~m}^{2}\right)$ caused the highest $\beta$-carotene losses (14.33 and $3.72 \%$, respectively). Elevated temperatures provided less decreased in $\beta$ carotene content of the samples. Ihns et al. (2011) observed that the retained $\beta$-carotene content of dried apricot increased with increasing temperature from 80 to $100^{\circ} \mathrm{C}$. They suggested that this is probably because the solubility of $\beta$-carotene increased at high temperature. Karabulut et al. (2007) ascribed the decrease in $\beta$-carotene due to oxidation with air; hence, 
samples dried for a longer drying time and lower temperatures, air velocities resulted in lower $\beta$-carotene contents. The samples dried with a lower trays load (125 $\mathrm{g} / 0.22 \mathrm{~m}^{2}$ ) resulted in lower pigments contents due to the more exposure to oxidation with air during drying process.

\section{Effect of hot air drying variables on total phenolics and total flavonoids contents of Jew's mallow leaves:}

Results in Table (2) showed that the initial contents of total phenolics and total flavonoids of fresh Jew's mallow leaves were $16.54 \pm 0.63 \mathrm{mg} \mathrm{GAE}$ and $117.88 \pm$ $1.34 \mathrm{mg}$ QE per g (dry weight) sample, respectively. Similarly, Bahlol et al. (2000) found that the polyphenols content of fresh Jew's mallow leaves was $18.60 \mathrm{mg} / \mathrm{g}$ (dry weight).

Hot air drying process led to decrease the total phenolics and flavonoids contents of Jew's mallow leaves (Table 2). A maximum reduction of 16.99 and $59.60 \%$ in comparison with fresh leaves in the total phenolics and flavonoids contents was shown in leaves dried at $50^{\circ} \mathrm{C}$, respectively. Increasing temperature led to increase the retention of the total phenolics and flavonoids contents. The lowest reduction in the total phenolics (12.58\%) and flavonoids (55.21\%) was observed in leaves dried at $60^{\circ} \mathrm{C}$ (Table 2). The differences between total phenolics content in leaves dried at 60 and $70^{\circ} \mathrm{C}$ were not significant $(\mathrm{P}<0.05)$. A probable reason for the high reductions observed at $50^{\circ} \mathrm{C}$ could be the long drying time required to achieve the equilibrium moisture content. The drying at low temperature did not inactivate the oxidative enzyme, resulted in oxidation of the phenolic compounds (Mrad et al., 2012). While, at $60{ }^{\circ} \mathrm{C}$, the increasing of retained contents could be due to the increase in release of compounds from the matrix that is more accessible in the extraction. This also, may be attributed to the inactivation of polyphenol oxidase enzyme, leading to the inhibition of polyphenols degradation (Yamaguchi et al., 2003) or because of the availability of precursors of phenolics by non-enzymatic inter-conversion between phenolic molecules (Que et al., 2008).
The insignificant decrease occurred at $70^{\circ} \mathrm{C}$ could be due to the oxidation and degradation, where the degradation of total phenolics was temperature dependent. Also, it can be attributed to the interaction of polyphenols with proteins or to alterations in the chemical structure which cannot be extracted or determined (Martín-Cabrejas et al., 2009 and Qu et al., 2010).

All thermal drying methods such as microwave, sun and oven drying resulted in a decrease in the total phenolic compounds of ginger leaves (Chan et al., 2009). The longer drying times resulted in higher degradation of phenolics in orange by-products and apple tissues (Garau et al., 2007 and Devic et al., 2010). Viña and Chaves (2008) found that drying celery at $48^{\circ} \mathrm{C}$ for one hour led to a $60 \%$ decrease in total flavonoids.

Drying Jew's mallow leaves at high air velocities led to an increase in the retained total phenolics and flavonoids contents (Table 2) in the dried product. This may be due to the reduction in drying times and thermal stress (Mrkic et al., 2006).

Table (2) showed also, the effect of trays load on the total phenolics and flavonoids contents of Jew's mallow leaves. There were significant increase in the retention of both contents with increasing the trays load; the higher the trays load, the higher the total phenolics and flavonoids contents retention. This result seems inconsistent with those obtained with air temperature and velocity. Where, longer drying time led to increasing of phenolics and flavonoids degradation. This could be attributed to the complex relationships between drying air temperature, velocity, trays load and drying time. The degradation of flavonoids during heat treatment is not only a function of temperature. It may depend on other parameters such as the presence of oxygen and other phytochemicals. The presence of oxygen induces high reductions in quercetin and rutin. Also, the presence of other phytochemicals such as chlorogenic acid plays a protective role (Ioannou et al., 2012).

Table (1): Effect of hot air drying variables on the main pigments contents (mg/100g dry weight) of Jew's mallow leaves

\begin{tabular}{|c|c|c|c|c|c|c|}
\hline \multirow{2}{*}{$\begin{array}{l}\text { Drying } \\
\text { variable }\end{array}$} & \multicolumn{2}{|c|}{ Chlorophyll a } & \multicolumn{2}{|c|}{ Chlorophyll b } & \multicolumn{2}{|c|}{$\beta$-carotene } \\
\hline & Content & Retention \% & Content & Retention \% & Content & Retention \% \\
\hline Fresh & $649.4 \pm 22.2^{\mathrm{a}}$ & 100 & $317.4 \pm 23.9^{\mathrm{a}}$ & 100 & $91.4 \pm 12.1^{\mathrm{a}}$ & 100 \\
\hline \multicolumn{7}{|c|}{ Air temperature $\left({ }^{\circ} \mathrm{C}\right)$} \\
\hline 50 & $103.9 \pm 15.8^{\mathrm{d}}$ & 16.00 & $25.3 \pm 6.8^{\mathrm{c}}$ & 9.97 & $78.3 \pm 29.0^{\mathrm{a}}$ & 85.67 \\
\hline 60 & $234.3 \pm 8.0^{\mathrm{c}}$ & 36.80 & $54.2 \pm 27.0^{\mathrm{bc}}$ & 17.08 & $122.5 \pm 47.2^{\mathrm{a}}$ & 134.03 \\
\hline $\mathbf{7 0}$ & $327.7 \pm 5.7^{\mathrm{b}}$ & 50.46 & $83.6 \pm 35.4^{\mathrm{b}}$ & 26.34 & $141.4 \pm 59.1^{\mathrm{a}}$ & 154.70 \\
\hline \multicolumn{7}{|c|}{ Air velocity $(\mathrm{m} / \mathrm{s})$} \\
\hline 0.2 & $155.9 \pm 27.8^{b}$ & 24.01 & $30.0 \pm 14.0^{b}$ & 9.45 & $96.1 \pm 26.2^{\mathrm{a}}$ & 105.14 \\
\hline 0.4 & $160.9 \pm 41.5^{\mathrm{b}}$ & 24.78 & $29.6 \pm 11.4^{\mathrm{b}}$ & 9.33 & $101.1 \pm 22.5^{\mathrm{a}}$ & 110.61 \\
\hline 0.6 & $163.3 \pm 15.9^{\mathrm{b}}$ & 25.15 & $34.5 \pm 14.6^{\mathrm{b}}$ & 10.87 & $99.5 \pm 37.7^{\mathrm{a}}$ & 108.86 \\
\hline \multicolumn{7}{|c|}{ Trays load $\left(\mathrm{g} / 0.22 \mathrm{~m}^{2}\right)$} \\
\hline 125 & $184.4 \pm 39.3^{\mathrm{c}}$ & 28.40 & $42.5 \pm 7.3^{b}$ & 13.39 & $88.0 \pm 29.5^{\mathrm{a}}$ & 96.28 \\
\hline 250 & $234.3 \pm 8.0 b^{c}$ & 36.08 & $54.2 \pm 27.0^{b}$ & 17.08 & $122.5 \pm 47.2^{\mathrm{a}}$ & 134.03 \\
\hline 375 & $261.8 \pm 42.6^{\mathrm{b}}$ & 40.31 & $54.7 \pm 20.4^{b}$ & 17.23 & $131.9 \pm 38.2^{\mathrm{a}}$ & 144.31 \\
\hline 500 & $239.5 \pm 38.1^{b c}$ & 36.88 & $47.9 \pm 20.9^{b}$ & 15.09 & $125.2 \pm 35.8^{\mathrm{a}}$ & 136.98 \\
\hline
\end{tabular}

Values are means \pm standard deviation of triplicate analyses.

Means within a column (for each variable) marked with different letters are significantly different at $(p<0.05)$. 
Table (2): Effect of hot air drying variables on total phenolics and total flavonoids contents (mg/g dry weight) of Jew's mallow leaves

\begin{tabular}{|c|c|c|c|c|}
\hline \multirow{2}{*}{ Drying variable } & \multicolumn{2}{|c|}{ Total phenolics } & \multicolumn{2}{|c|}{ Total flavonoids } \\
\hline & Content & Retention \% & Content & Retention \% \\
\hline Fresh & $16.54 \pm 0.63^{\mathrm{a}}$ & 100 & $117.88 \pm 1.34^{\mathrm{a}}$ & 100 \\
\hline \multicolumn{5}{|c|}{ Air temperature $\left({ }^{\circ} \mathrm{C}\right)$} \\
\hline 50 & $13.73 \pm 0.19^{\mathrm{c}}$ & 83.01 & $47.62 \pm 2.30^{b}$ & 40.40 \\
\hline 60 & $14.46 \pm 0.08^{b}$ & 87.42 & $52.80 \pm 2.40^{\mathrm{b}}$ & 44.79 \\
\hline $\mathbf{7 0}$ & $14.20 \pm 0.16^{\mathrm{bc}}$ & 85.85 & $52.12 \pm 5.99^{b}$ & 44.21 \\
\hline \multicolumn{5}{|l|}{ Air velocity (m/ s) } \\
\hline 0.2 & $15.51 \pm 0.20^{b}$ & 93.77 & $50.77 \pm 6.19^{b}$ & 43.07 \\
\hline 0.4 & $15.21 \pm 0.31^{\mathrm{b}}$ & 91.96 & $48.74 \pm 7.08^{b}$ & 41.35 \\
\hline 0.6 & $16.28 \pm 0.34^{\mathrm{a}}$ & 98.43 & $52.30 \pm 3.11^{\mathrm{b}}$ & 44.37 \\
\hline \multicolumn{5}{|c|}{ Trays load $\left(\mathrm{g} / 0.22 \mathrm{~m}^{2}\right)$} \\
\hline 125 & $14.36 \pm 0.19^{c}$ & 86.82 & $50.28 \pm 5.20^{c}$ & 42.65 \\
\hline 250 & $14.46 \pm 0.08^{\mathrm{c}}$ & 87.42 & $52.80 \pm 2.40^{\mathrm{c}}$ & 44.79 \\
\hline 375 & $15.51 \pm 0.03^{b}$ & 93.77 & $59.06 \pm 0.99^{b}$ & 50.10 \\
\hline 500 & $15.82 \pm 0.82^{\mathrm{ab}}$ & 95.65 & $60.93 \pm 3.87^{\mathrm{b}}$ & 51.69 \\
\hline
\end{tabular}

Values are means \pm standard deviation of triplicate analyses.

Means within a column (for each variable) marked with different letters are significantly different at $(p<0.05)$.

Effect of hot air drying variables on the antioxidant activity of Jew's mallow leaves:

Results are presented in Table (3) showed the DPPH-radical scavenging activity and average antioxidant capacity (TEAC assay) of fresh and dried Jew's mallow leaves under different drying variables. Fresh Jew's mallow leaves exhibited high DPPH radical scavenging activity $(52.29 \%$, dry weight) and antioxidant capacity (139.55 $\mu \mathrm{mol}$ trolox/ g, dry weight). Leaves dried at 50 and $70{ }^{\circ} \mathrm{C}$ exhibited the lowest DPPH and TEAC scavenging activities. Meanwhile, leaves dried at $60^{\circ} \mathrm{C}$ had the highest ones. The increase in the retained antioxidant activity after drying at $60{ }^{\circ} \mathrm{C}$ may be attributed to the release of phenolic compounds by the breakdown of cellular constituents (Chan et al., 2009), and the formation of new compounds such as Maillard reaction products, which having antioxidant activity (Manzocco et al., 2001). Drying at low temperature (such as $50^{\circ} \mathrm{C}$ ) led to decrease the antioxidant activity. This behavior could be related to the long drying time that may be cause a decrease of antioxidant activity (Garau et al., 2007). Drying time was the critical factor in broccoli dehydration. Short drying times, through use of high temperature and increased air flow maximized the antioxidant activity (Mrkic et al., 2006). The negative effect of high temperature $\left(70{ }^{\circ} \mathrm{C}\right)$ on antioxidant activity could be ascribed to its depleting effect via oxidation or degradation on phytochemicals (Katsube $e t$ al., 2009).

Table (3): Effect of hot air drying variables on DPPH and $\mathrm{ABTS}^{\cdot+}$ scavenging activities of Jew's mallow leaves.

\begin{tabular}{|c|c|c|c|c|}
\hline \multirow[b]{2}{*}{ Drying variable } & \multicolumn{2}{|c|}{ DPPH radical-scavenging activity } & \multicolumn{2}{|c|}{ ABTS $^{\bullet+}$} \\
\hline & (\%, dry weight) & Retention \% & $\begin{array}{c}\text { ( } \mu \text { mol trolox/g dry } \\
\text { weight) }\end{array}$ & Retention \% \\
\hline Fresh & $52.29 \pm 2.84^{\mathrm{a}}$ & 100 & $139.55 \pm 7.48^{\mathrm{a}}$ & 100 \\
\hline \multicolumn{5}{|c|}{ Air temperature $\left({ }^{\circ} \mathrm{C}\right)$} \\
\hline $\mathbf{5 0}$ & $36.11 \pm 0.74^{\mathrm{c}}$ & 69.06 & $42.16 \pm 0.34^{b}$ & 30.21 \\
\hline 60 & $42.59 \pm 0.27^{b}$ & 81.45 & $44.79 \pm 3.68^{b}$ & 32.10 \\
\hline 70 & $37.30 \pm 0.24^{\mathrm{c}}$ & 71.33 & $37.77 \pm 1.72^{b}$ & 27.07 \\
\hline \multicolumn{5}{|l|}{ Air velocity $(\mathrm{m} / \mathrm{s})$} \\
\hline 0.2 & $42.17 \pm 0.54^{\mathrm{c}}$ & 80.65 & $41.71 \pm 0.80^{b}$ & 29.89 \\
\hline 0.4 & $42.41 \pm 1.92^{\mathrm{bc}}$ & 81.11 & $41.72 \pm 2.04^{\mathrm{b}}$ & 29.90 \\
\hline 0.6 & $46.23 \pm 2.20^{\mathrm{b}}$ & 88.41 & $43.34 \pm 0.01^{\mathrm{b}}$ & 31.06 \\
\hline \multicolumn{5}{|c|}{ Trays load $\left(\mathrm{g} / 0.22 \mathrm{~m}^{2}\right)$} \\
\hline 125 & $41.87 \pm 1.69^{b}$ & 80.07 & $41.52 \pm 1.71^{b}$ & 29.75 \\
\hline 250 & $42.59 \pm 0.27^{\mathrm{b}}$ & 81.45 & $44.79 \pm 3.68^{b}$ & 32.10 \\
\hline 375 & $43.23 \pm 0.68^{b}$ & 82.67 & $45.80 \pm 2.41^{\mathrm{b}}$ & 32.82 \\
\hline 500 & $44.41 \pm 1.21^{\mathrm{b}}$ & 84.93 & $50.56 \pm 7.92^{b}$ & 36.23 \\
\hline
\end{tabular}

Values are means \pm standard deviation of triplicate analyses.

Means within a column (for each variable) marked with different letters are significantly different at $(p<0.05)$.

Data presented in Table (3) showed that the antioxidant activity of dried Jew's mallow leaves correlated positively with air velocity. This could be due to the reduction in drying time. Also showed the positive correlations between trays load and antioxidant activity of dried Jew's mallow leaves. This result seemed inconsistent with those obtained in air temperature and velocity, where shorter drying times 
enhanced the antioxidant activity. In this case, the highest load and longer drying time, the highest antioxidant activity. This could be related to generation and accumulation of different antioxidant compounds developing antagonistic or synergistic effects with other constituents or with themselves (Zielisnki and Koslowska, 2000).

Many studies have reported on the relationships between phytochemicals, especially phenolics and antioxidant activity. Increasing correlation between antioxidant activity and total phenolics content has been reported during food dehydration. A plot of antioxidant activity measured by DPPH or TEAC assay versus phytochemical compounds studied showed a strong positive correlation with chlorophyll a $\left(\mathrm{r}^{2}=0.791-\right.$ $1.00)$, chlorophyll $\mathrm{b}\left(\mathrm{r}^{2}=0.848-1.00\right)$, total phenolics $\left(r^{2}=0.823-0.955\right)$ and total flavonoids $\left(r^{2}=0.868-\right.$ 0.999) (data not shown). This indicating that these compounds are useful predictors of antioxidant activity of Jew's mallow leaves.

\section{CONCLUSION}

The results of the present study showed the importance of Jew's mallow leaves as a good source of natural antioxidants. Drying process variables had significant effects on the antioxidant activity and phytochemical compounds of Jew's mallow leaves. Optimizing the drying process of Jew's mallow is important to maintain its desirable properties. From nutrition point of view, dried leaves can be used in many food products such as snacks or extrudates (article in preparation) to enhance their nutritional properties.

\section{REFERENCES}

Adegoke, A. and B. Adebayo-Tayo (2009). Phytochemical composition and antimicrobial effects of Corchorous olitorius leaf extracts on four bacterial isolates. J. Medic. Plants Res., 3: 155-159.

Ali, H. M. and I. A. Sokr (1982). Drying of vegetables in Egypt. International Development Research Center Monographs, IDRC-195e. (pp. 15-19).

Antolovich, M., P. Prenzler, K. Robards and D. Ryan (2000). Sample preparation in the analysis of phenolic compounds in fruits. The Analyst, 125: 989-1009.

AOAC (2000). Official method of analysis (16 ${ }^{\text {th }}$ Ed.). Association of Official Analytical Chemists, Washington DC.

Azuma, K., M. Nakayama, M. Koshioka, K. Ippoushi, Y. Yamaguchi, K. Kohata, Y. Yamauchi, H. Ito and H. Higashio (1999). Phenolic antioxidants from the leaves of Corchorus olitorius L. J. Agric. Food Chem., 47: 3963-3966.

Bahlol, H. E. M., H. A. El-Mansy, A. M. Nezam El-Din and H. M. A. Abo-Taleb (2000). Studies on some preservation methods of Jew's mallow leaves "Moulokeia". Annals Agric. Sci. Moshtohor, 38: 969-981.

Barros, L., L. Cabrita, M. V. Boas, A. M. Carvalho and I. C. F. R. Ferreira (2011). Chemical, biochemical and electrochemical assays to evaluate phytochemicals and antioxidant activity of wild plants. Food Chem., 127: 1600-1608.
Chan, E. W. C., Y. Y. Lim, S. K. Wong, K. K. Lim, S. P. Tan, F. S. Lianto and M. Y. Yong (2009). Effect of different drying methods on the antioxidant properties of leaves and tea of ginger species. Food Chem., 113: 166-172.

Dai, Q., A. R. Borenstein, Y. Wu, J. C. Jackson and E. B. Larson (2006). Fruit and vegetable juices and Alzheimer's disease: The Kame Project. The American J. Medic., 119: 751-759.

Decker, E. A. (1995). The role of phenolics, conjugated linoleic acid, carnosine, and pyrrolquinoline quinone as nonessential dietary antioxidants. Nutr. Rev., 53: 49-58.

Devic, E., S. Guyot, J. D. Daudin and C. Bonazzi (2010). Kinetics of polyphenol losses during soaking and drying of cider apples. Food Bioproc. Technol., 3: 867-877.

Dewanto, V., X. Wu, K. K. Adom and R. H. Liu (2002). Thermal processing enhances the nutritional value of tomatoes by increasing total antioxidant activity. J. Agric. Food Chem., 50: 3010-3014.

Furumoto, T., R. Wang, K. Okazaki, A. F. M. F. Hasan, M. I. Ali, A. Kondo and H. Fukui (2002). Antitumor promoters in leaves of jute (Corchorus capsularis and Corchorus olitorius). Food Sci. Technol. Res., 8: 239-243.

Garau, M. C., S. Simal, C. Rosselló and A. Femenia (2007). Effect of air-drying temperature on chemical properties of dietary fibre and antioxidant capacity of orange (Citrus aurantium $\mathrm{v}$ Canoneta) byproducts. Food Chem., 104: 1014-1024.

Handoussa, H., R. Hanafi, I. Eddiasty, M. El-Gendy, A. El-Khatib, M. Linscheid, L. Mahran and N. Ayoub (2013). Anti-inflammatory and cytotoxic activities of dietary phenolics isolated from Corchorus olitorius and Vitis vinifera. J. Functional Foods 5: 1204-1216.

Hertog, M. G. L. and P. C. H. Hollman (1996). Potential health effects of dietary flavonol quercetin. Eur. J. Clinic. Nutr., 50: 63-71.

Hossain, M. A. and S. M. M. Rahman (2011). Total phenolics, flavonoids and antioxidant activity of tropical fruit pineapple. Food Res. Int., 44: 672-676.

Hunter, K. J. and J. M. Fletcher (2002). The antioxidant activity and composition of fresh, frozen, jarred and canned vegetables. Innov. Food Sci. and Emerg. Technol., 3: 399-406.

Hussein, A. A. A. (1983). Comparative study on the dehydration process of fruits and vegetables. Ph.D. Theses, Faculty of Agriculture, Cairo University, Egypt.

Ihns, R., L. M. Diamante, G. P. Savage and L. Vanhanen (2011). Effect of temperature on the drying characteristics, color, antioxidant and betacarotene contents of two apricot varieties. Int. J. Food Sci. Technol., 46: 275-283.

Innami, S., K. Nakamura, K. Tabata, M. Wada and T. Takita (1995). Water-soluble viscous substance of Jew's mellow leaves lowers serum and liver cholesterol concentrations and increases fecal steroid excretion in rats fed a high cholesterol diet. J. Nutr. Sci. Vitaminol., 41: 465-475. 
Ioannou, I., I. Hafsa, S. Hamdi, C. Charbonnel and M. Ghoul (2012). Review of the effects of food processing and formulation on flavonol and anthocyanin behavior. J. Food Eng., 111: 208-217.

Karabulut, I., A. Topcu, A. Duran, S. Turan and B. Ozturk (2007). Effect of hot air drying and sun drying on color values and $\beta$-carotene content of apricot (Prunus armenica L.). LWT, 40: 753-758.

Katsube, T., Y. Tsurunaga, M. Sugiyama, T. Furuno and Y. Yamasaki (2009). Effect of air-drying temperature on antioxidant capacity and stability of polyphenolic compounds in mulberry (Morus alba L.) leaves. Food Chem., 113: 964-969.

Labib, A. A. S., S. A. Abd El-Latife and H. Omran (1997). Quality indices of Jew's mallow and spinach during frozen storage. Plant Foods Human Nutr., 50: 333-347.

Lee, J. Y., E. O. Choe, K. H. Park and S. H. Lee (2001). Effects of heat pretreatment on lipid and pigments of freeze-dried spinach. J. Food Sci., 66: 1074-1079.

Lee, S. C., J. H. Kim, S. M. Jeong, D. R. Kim, J. U. Ha and K. C. Nam (2003). Effect of far infrared radiation on the antioxidant activity of rice hulls. $\mathrm{J}$. Agric. Food Chem., 51: 4400-4403.

Manzocco, L., S. Calligaris, D. Mastrocola, M. Nicoli and C. Lerici (2001). Review of non enzymatic browning and antioxidant capacity in processed foods. Trends Food Sci. Technol., 11: 340-346.

Martín-Cabrejas, M. A., Y. Aguilera, M. Pedrosa, C. Cuadrado, T. Hernández, S. Díaz and R. M. Esteban (2009). The impact of dehydration process on antinutrients and protein digestibility of some legume flours. Food Chem., 114: 1063-1068.

Martínez, G. A., P. M. Civello, A. R. Chaves and M. C. Añón (2001). Characterization of peroxidasemediated chlorophyll bleaching in strawberry fruit. Phytochem., 58: 379-387.

Matile, P., S. Hörtensteiner and H. Thomas (1999). Chlorophyll degradation. Annual Rev. Plant Physiol. Plant Molec. Biol., 50: 67-95.

Mrad, N. D., N. Boudhrioua, N. Kechaou, F. Courtois and C. Bonazzi (2012). Influence of air drying temperature on kinetics, physicochemical properties, total phenolic content and ascorbic acid of pears. Food Biopro. Proc., 90: 433-441.

Mrkic, V., E. Cocci, M. D. Rosa and G. Sacchetti (2006). Effect of drying conditions on bioactive compounds and antioxidant activity of broccoli (Brassica oleracea, L). J. Sci. Food Agric., 86: 1559-1566.

Murcia, M. A., A. M. Jiménez and M. Martínez-Tomé (2009). Vegetables antioxidant losses during industrial processing and refrigerated storage. Food Res. Int., 42: 1046-1052.

Oboh, G. and J. B. T. Rocha (2007). Distribution and antioxidant activity of polyphenols in ripe and unripe tree pepper (Capsicum pubescens). J. Food Biochem., 31: 456-473.

Oboh, G., A. Ademiluyi, A. Akinyemi, T. Henle, J. Saliu and U. Schwarzenbolz (2012). Inhibitory effect of polyphenol-rich extracts of jute leaf (Corchorus olitorius) on key enzyme linked to type 2 diabetes ( $\alpha$-amylase and $\alpha$-glucosidase) and hypertension (angiotensin I converting) in vitro. J. Functional Foods, 4: 450-458.

Pappas, E. and K. M. Schaich (2009). Phytochemicals of cranberries and cranberry products: Characterization, potential health effects, and processing stability. Crit. Rev. Food Sci. Nutr., 49: 741-781.

Phuwapraisirisan, P., T. Puksasook, U. Kokpol and K. Suwanborirux (2009). Corchorusides A and B, new flavonol glycosides as $\alpha$-glucosidase inhibitors from the leaves of Corchorus olitorius. Tetra. Letters 50: 5864-5867.

Qu, W., Z. Pan and H. Ma (2010). Extraction modeling and activities of antioxidants from pomegranate marc. J. Food Eng., 99: 16-23.

Que, F., L. Mao, X. Fang and T. Wu (2008). Comparison of hot air-drying and freeze-drying on the physicochemical properties and antioxidant activities of pumpkin (Cucurbita moschata Duch.) flours. Int. J. Food Sci. Technol., 43: 1195-1201.

Ravichandran, K., N. M. M. T. Saw, A. A. A. Mohdaly, A. M. M. Gabr, A. Kastell, H. Riedel, Z. Cai, D. Knorr and I. Smetanska (2013). Impact of processing of red beet on betalain content and antioxidant activity. Food Res. Int., 50: 670-675.

Rufino, M. S. M., R. E. Alves, E. S. de Brito, J. PérezJiménez, F. Saura-Calixto and J. Mancini-Filho (2010). Bioactive compounds and antioxidant capacities of 18 non-traditional tropical fruits from Brazil. Food Chem., 121: 996-1002.

Schwartz, S. J. and T. V. Lorenzo (1991). Chlorophyll stability during continuous aseptic processing and storage.J. FoodSci., 56: 1059-1062.

Vega-Gálvez, A., K. Di Scala, K. Rodríguez, R. LemusMondaca, M. Miranda, J. López and M. Perez-Won (2009). Effects of air-drying temperature on physico-chemical properties, antioxidant capacity, colour and total phenolic content of red pepper (Capsicum annuum, L. var. Hungarian). Food Chem., 117: 647-653.

Viña, S. Z. and A. R. Chaves (2008). Effect of heat treatment and refrigerated storage on antioxidant properties of pre-cut celery (Apium graveolens L.). Int. J. Food Sci. Technol., 43: 44-51.

Von Elbe, J. H. and S. J. Schwartz (1996). Colorants. In: O. R. Fennema (Ed.), Food Chemistry (pp. 651722). Marcel Dekker, New York.

Yamaguchi, T., M. Katsuda, Y. Oda, J. Terao, K. Kanazawa, S. Oshima, T. Inakuma, Y. Ishiguro, H. Takamura and T. Matoba (2003). Influence of polyphenol and ascorbate oxidases during cooking process on the radical-scavenging activity of vegetables. Food Sci. Technol. Res., 9: 79-83.

Zakaria, Z. A., M. N. Somchit, H. Zaiton, A. M. Mat Jais, M. R. Sulaiman, W. O. Farah, R. Nazaratulmawarina and C. A. Fatimah (2006). The in vitro antibacterial activity of Corchorus olitorius extracts. Int. J. Pharm., 2: 213-215.

Zielisnki, H. and H. Koslowska (2000). Antioxidant activity and total phenolics in selected cereal grains and their different morphological fractions. J. Agric. Food Chem., 48: 2008-2016. 


\section{تأثير عوامل التجفيف بالهواء الساخن في المركبات الحيوية والنشاط المضاد للأكسدة لأوراق الملوخية

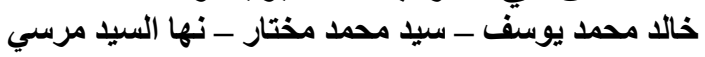

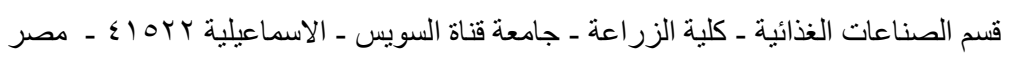

تعتبر الملوخية من محاصيل الخضر الهامة في مصر ، والتي يتعاظم الطلب عليها سواء في صورة طازجة أو مجفقة محليا وخارجيا.

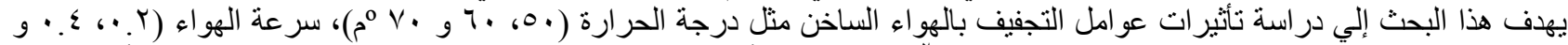

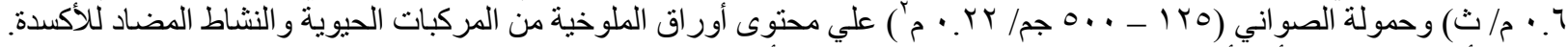

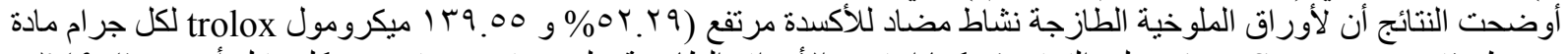

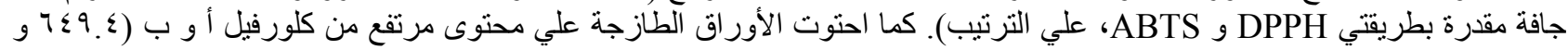

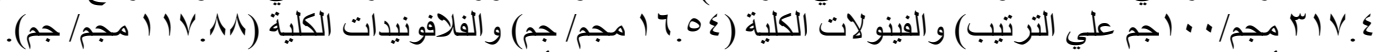

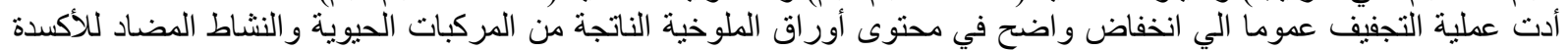

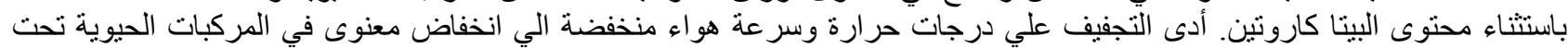

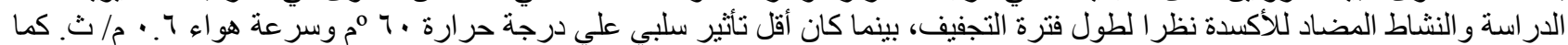

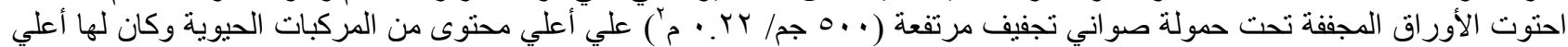

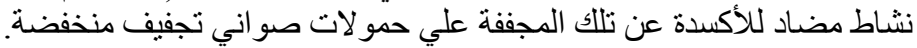

